\title{
Maquiladoras and informality: a mixed blessing*
}

\author{
Benedikt Heid ${ }^{\dagger}$, Mario Larch; Alejandro Riaño§
}

December 1, 2011

\begin{abstract}
Mexico experienced a tremendous expansion of its export-processing maquila sector during the 1990s. At the same time, a large proportion of its labor force remains employed in the informal sector. Since one of the main objectives of the maquiladora program was to increase formal employment, we study how the rapid increase in maquiladora activity has affected labor market outcomes in Mexico. We develop a heterogeneous firm model with imperfect labor markets that captures salient features of the Mexican economy such as the differences between maquila and non-maquila manufacturing plants and the existence of an informal sector. We calibrate the model's parameters to match key cross-sectional moments characterizing the Mexican economy. Our quantitative model indicates that the expansion of the maquila sector during the 1990s produced an increase in informality of $0.9 \%$ and a reduction in the skill premium and overall welfare of $2.7 \%$ and $3.7 \%$ respectively. A counterfactual experiment in which we shut down the informal sector completely results in a reduction of Mexican welfare of $33.5 \%$ relative to the equilibrium with an informal sector.
\end{abstract}

JEL codes: F12, F14, F16, F23, O24

Keywords: Offshoring, informal sector, maquilas, trade and labor markets, Mexico

*Funding from the Leibniz-Gemeinschaft (WGL) under project "Pakt 2009 Globalisierungsnetzwerk" is gratefully acknowledged. We thank Guiseppe Celi, Hartmut Egger, Peter Egger, Paul Frijters, Benjamin Jung, Zhihong Yu, and participants of the Midwest International Trade Meetings Spring 2011, XXV Annual Conference of the European Society for Population Economics 2011, DEGIT-XVI conference, University of Bari Second International Workshop on the Economics of Global Interactions, Göttingen, EGIT Munich, and Nottingham PhD Postgraduate Conference workshops as well as ETH Zürich, University of Bayreuth and ifo Institute for Economic Research Munich internal seminars for helpful comments. Also many thanks to the staff at INEGI for their support. The usual disclaimer applies.

${ }^{\dagger}$ University of Bayreuth and ifo Institute Munich, benedikt.heid@uni-bayreuth.de

¥niversity of Bayreuth, ifo Institute Munich, CESifo, and GEP, mario.larch@uni-bayreuth.de

${ }^{\S}$ University of Nottingham, GEP, CFCM, and CESifo, alejandro.riano@nottingham.ac.uk 


\section{Introduction}

Policymakers and the popular press in developed countries have grown increasingly worried about the labor market impact of offshoring, the relocation of production tasks to low-wage locations. While most researchers studying this trend have focused on how this phenomenon affects source countries, relatively few studies have investigated the impact of offshoring on the developing countries on the receiving end.

As pointed out by many researchers however, the offshoring phenomenon is not new, and has in fact played an important role on many developing countries' economic strategy to integrate in the global economy. Mexico is perhaps one of the best examples to illustrate this fact. Over the past three decades Mexico has transitioned from being a fairly closed economy to becoming one of the most open countries in the world.

One of the key drivers of Mexico's impressive export growth has been the maquila sector. Maquila plants, or maquiladoras for short, are assembly plants which are mostly located along a $20-\mathrm{km}$ strip along the US-Mexico border. The key defining characteristic of maquiladoras is their exclusive focus on assembling purchased intermediate inputs which are then re-exported as finished goods. Although the maquiladora program was formally started in the 1960s, it was at the end of the 1980s, after the first round of trade and investment liberalization reforms, that the sector started booming, its value-added growing at an average rate of $10 \%$ per year (relative to a $3 \%$ growth rate of non-maquila manufacturing) which had led it to account for about $8.3 \%$ of manufacturing value-added, $47.1 \%$ of manufacturing employment and $52.9 \%$ of aggregate exports in 2004.

Hopes amongst Mexican politicians were high that the increase in labor demand brought about by the expansion of the maquiladora sector would create industrial sector jobs and decrease informal sector employment. Employment in the informal sector is commonly viewed as undesirable as workers are assumed to only turn to the informal sector when they cannot find a formal sector job. Most informal sector workers are either self-employed or work in small scale, low-productivity establishments. There, they earn wages which are substantially lower than wages in formal sector firms. Sometimes workers do not receive any monetary payment at all but are paid in kind, especially in family-owned establishments. The informal sector is especially rampant in Mexico where it represents 30 to $50 \%$ of the labor force, depending on the exact definition used. Policy makers therefore hoped that the expansion of the maquila sector would replace informal sector jobs by formal sector jobs in the maquila sector, see e.g. Martin (2000) and see Villarreal (2010).

Alternatively, the mere existence of an informal sector can prop up formal sector wages, even though formal workers receive strictly higher wages than their informal counterparts. The outside option of voluntarily picking up a job in the informal sector when a formal sector job is not attractive enough can be used as a threat in the wage bargaining process. ${ }^{1}$

This paper investigates whether the rapid expansion of the maquila sector has been a

\footnotetext{
${ }^{1}$ For the view that a substantial number of individuals working in the informal sector do so voluntarily, see Maloney (1998).
} 
panacea for Mexico, or if it has been a mixed blessing instead. In order to quantify how the expansion of the maquila sector has affected welfare and labor market outcomes, we calibrate a small open economy two sector, two factor model of trade with firm heterogeneity to match key cross-sectional moments of the Mexican economy. Our counterfactual analysis indicates that an increase in the foreign demand for maquila output consistent with the observed expansion of the sector during the 1990s decreases Mexico's welfare and increases the size of the informal sector. In a second experiment in which we let the labor market for unskilled workers to be perfectly competitive, we find that welfare is lower than in the economy with an informal sector.

The intuition for this result is that taking away the possibility for workers to work in the informal sector hurts their bargaining power. As workers cannot opt out from working in the formal sector, unskilled wages will be lower. If workers can use informality as an outside option in their wage bargaining process, foreign maquiladora owners repatriate a smaller amount of profits thus increasing income available for domestic consumption in Mexico. This mechanism directly increases welfare.

In our model we take into account that maquiladoras are substantially different from nonmaquiladora manufacturing plants in several dimensions. We identify four dimensions that encompass their main differences, namely maquiladoras (i) are less skill-intensive (their share of production workers in total employment tends to be higher than that of standard manufacturing plants), (ii) use a high share of imported intermediate inputs, (iii) are more likely to be foreign-owned and (iv) are on average larger in terms of total employment than non-maquila manufacturing plants. Our modeling framework of a two sector, two factor economy with firm heterogeneity as in Bernard, Redding and Schott's (2007) extension of the Melitz (2003) model allows us to incorporate the differences between maquiladoras and regular manufacturing firms described previously.

Concerning informality, our model seeks to incorporate three main stylized facts about labor markets in Mexico: (i) A large share of the labor force is active in the informal sector, (ii) the vast majority of informal workers have low educational attainment and (iii) there is a formality premium: informal workers earn on average wages that are $29 \%$ lower than those of comparable individuals employed in the formal sector.

We incorporate informality into the model by means of a search and matching framework as in Zenou (2008), Satchi and Temple (2009), and Albrecht, Navarro, and Vroman (2009). Specifically, we assume that only unskilled workers face search frictions in the labor market. Workers which do not find a job end up in the informal sector. While Zenou (2008) and Albrecht et al. (2009) study the impact of different labor market and tax policies for typical developing countries with an informal sector, Satchi and Temple (2009) present a calibrated model of the Mexican economy. As all these papers focus on the impact of labor market policies, they share a very stylized view of the production side as they only consider one worker firms. They also abstract from the foreign-owned maquila sector and do not model the self-selection of more productive firms into exporting. 
There are alternative approaches to modeling the informal sector which do not rely on search frictions and which are complementary to ours. For example, whereas in our framework firms cannot hire informal workers, Ulyssea (2010) assumes that consumption goods are produced by a combination of intermediate goods produced in both the formal and informal sector. Similarly, in Marjit, Ghosh, and Biswas (2007) firms decide on the optimal amount of formal and informal workers they hire.

Suffice to say that our model does not incorporate all facets of informality. Our modeling framework advances the literature by taking into account the existence of the informal sector in the presence of maquiladora plants. Importantly, our model does not aim to model the complex reasons why the informal sector arises. It simply tries to flesh out the implications of the existence of the informal sector while modeling it in a very stylized way.

Our explicit modeling of the maquila sector contributes to the literature combining heterogeneous firm models of trade with labor market frictions (Felbermayr, Prat, and Schmerer, 2011, and Helpman and Itskhoki, 2010), and a large body of work studying the causes, consequences and implications of informality in developing countries. Additionally, we believe that taking into account the significant size of the informal sector in Mexico sheds new light on the aggregate impact of the expansion of the maquila sector studied by Feenstra and Hanson (1996) and Bergin, Feenstra, and Hanson (2009).

While this paper focuses on the case of Mexico, it has far more general implications as its modeling framework can also be applied to other countries in Latin America, Eastern Europe and Asia. These regions have experienced large inflows of foreign direct investment and created export processing zones (EPZs) similar to the Mexican maquiladora program. By 2006, 130 countries had established more than 3,500 EPZs accounting for 66 million employees world-wide. ${ }^{2}$ Crucially, these regions are also characterized by large informal sectors. ${ }^{3}$ Our paper therefore contributes to the more general literature on labor market effects of offshoring in developing and middle income countries. ${ }^{4}$

The remainder of the paper is structured as follows: Section 2 presents key stylized facts of the Mexican maquila industry and the informal sector. Section 3 presents our model. Section 4 gives details on chosen parameter values, presents the empirical moments matched by the model and evaluates its fit to the data. We present counterfactual results and evaluate the rise of the maquiladoras during the 1990s and its linkage to the informal sector using the calibrated model in section 5. Section 6 concludes.

\footnotetext{
${ }^{2}$ China alone accounts for 40 million employees, Latin America for 5.5 million employees, the transition economies in Eastern Europe for 1.4 million employees; for further details, see Boyenge (2007).

${ }^{3}$ For a survey on levels of informality throughout Latin America, see Gasparini and Tornarolli (2009). For a comparative world-wide survey, see Jütting and de Laiglesia (2009).

${ }^{4}$ See Chandra and Khan (1993) for a model of capital inflows in the presence of an informal sector. However, they do not model the activity of export-oriented foreign-owned firms as we do.
} 


\section{Stylized facts on the Mexican economy}

\subsection{The rise of the maquila sector}

The beginning of the maquila phenomenon dates back to the 1960s when the Programa de Industrialización de la Frontera Norte (Industrialization Program for the Northern Border) was put into place to promote the creation of export-processing plants in the Northern part of Mexico. The key defining characteristic of maquiladoras is their focus on assembling purchased intermediate inputs which are then re-exported as finished goods to the US: Their intermediates cost share was about $90 \%$ of total production costs in $2000 .^{5}$ These inputs are nearly exclusively sourced from abroad: In 2000, $97 \%$ of all intermediate goods used in maquiladoras were imported. ${ }^{6}$

After Mexico began removing restrictions on foreign ownership in 1986, the maquiladora program induced a structural shift towards a more foreign-oriented manufacturing sector in Mexico. ${ }^{7}$ Accordingly, most of maquiladora plants are foreign-owned (64\% versus $22 \%$ of non-maquila manufacturing plants). Hence, profits generated in the sector are moved abroad. Ramirez (2006) presents evidence that overall remittances of profits and dividends from Mexico more than doubled from 1990 to 2000 (from US $\$ 2.3$ to $\$ 5.2$ billion).

Consequently, maquila-related investment made up a significant share of Mexico's inward FDI between 1994 and 2000, doubling from 8.4 to 17\% of annual FDI inflows (Waldkirch, 2010). From 1980 to 1998, more than 60\% of these FDI flows into Mexico came from the US (Graham and Wada, 2000). After the implementation of NAFTA in 1994, maquila production experienced a major expansion, both in terms of output produced as well as in terms of employment. Figure 1 shows the increase of the value added in the maquila sector from 1990 to $2004 .^{8}$ During this period, value added has more than doubled. Over the same period, we observe an increase of the share of maquila exports in total exports from $49.4 \%$ to $53.0 \%$, see Figure 3. Not only have maquiladoras proven to be an important source of foreign currency, they also gained tremendous importance in terms of jobs over this period. The number of employees in the maquila plants increased from 450,000 to 1,115,000 persons in total. This translates into an increase from $1.5 \%$ to $3.7 \%$ of the total labor force from 1994 to 2004, and an increase from $15.4 \%$ to $34.3 \%$ of total manufacturing employment, see Figure 2 . This rise of the maquiladoras mainly came at the expense of standard manufacturing firms, as the overall share of manufacturing in GDP remained stable at about $18 \%$ during the same time period, see Figure 4.

\footnotetext{
${ }^{5}$ Calculated from Sistema de Cuentas Nacionales de México (Mexican National Accounts System) from INEGI (Instituto Nacional de Estadística y Geografía, National Statistics and Geography Institute), Mexico's federal statistical agency.

${ }^{6}$ Calculated from EIM (Encuesta Industrial Mensual, Monthly Industry Survey) from INEGI.

${ }^{7}$ See Kehoe (1995) for an account of Mexico's trade and investment liberalization reforms.

${ }^{8}$ More recent data are not available as the Mexican statistical office INEGI discontinued its survey of maquila plants, Estadística de la Industria Maquiladora de exportación (EIM) in 2006. Since 2007, maquila plants are incorporated in the survey Industria Manufacturera, Maquiladora y de servicios de EXportación (IMMEX), hence the data do not allow to discriminate between maquila and standard manufacturing plants after 2006 .
} 


\subsection{Informality and the Mexican labor market}

The literature on jobs in the informal sector uses different definitions of which job characteristics constitute an informal job. ${ }^{9}$ This reflects partly that definitions of informality have evolved over the last decades. Earlier studies stress informality as a concept referring to a specific sector of the economy. This productive definition focuses establishment-level characteristics. Enterprises belong to the informal sector when they operate "with scarce or even no capital, using primitive technologies and unskilled labor, and then with low productivity" as in the ILO (1993) definition of the informal sector. Maloney (2004) characterizes the informal sector as a wide array of small-scale, semi-legal, low-productivity frequently family-based establishments. More recently, emphasis has moved away from enterprise centered definitions towards informal employment, recognizing the fact that informal employment can arise both in formal as well as informal establishments. For example, formal businesses may subcontract informal workers to cut labor costs as a response to increasing competition. ${ }^{10}$ This legalistic definition of informality comprises employees and self-employed which do not have access to social security benefits like e.g. health-care or pension systems, but also workers who do not have a written work contract. ${ }^{11}$ As data on informality are often scarce, proxies like the share of the low-skilled self-employed in the labor force are also used to measure informality. Hence, depending on one's definition, informality can refer to very heterogeneous economic conditions.

In Figure 5 we present estimates of the percentage of the labor force active in the informal sector from two different sources using different definitions of informality. Binelli and Attanasio (2010) use the ENEU ${ }^{12}$ to calculate the share of informal workers by considering all individuals aged between 25 and 60 that are actively working at the time of the inclusion in the sample. They use a legalistic definition of informality by considering a worker to be informal when she does not contribute to social security.

The second source we use are quarterly data on the share of informal workers from the ENEO. ${ }^{13}$ This is the informal sector employment share published by INEGI using a productive definition of informality. Hence an individual is counted as informal when she works in an informal establishment. Another difference is the calculation of the economically active population as INEGI uses all individuals aged between 14 and 98 .

No matter which definition and which data sample is used, however, a clear pattern emerges: The hoped-for reduction in the informal sector employment rate did not materialize, even though at the same time foreign investments into Mexico and accompanying maquila activity soared. As indicated by Figure 5, there is no discernible trend in the informal sector

\footnotetext{
${ }^{9}$ For a detailed overview of informality definitions see Jütting and de Laiglesia (2009).

${ }^{10}$ See Sanchez, Joo and Zappala (2001), as cited in Maloney (2004).

${ }^{11}$ For the terms productive and legalistic definition of informality, see Gasparini and Tornarolli (2009).

${ }^{12}$ Encuesta Nacional de Empleo Urbano, the Mexican Employment Survey conducted by INEGI. The ENEU is available from 1987 to 2004 .

${ }^{13}$ Encuesta Nacional de Ocupación y Empleo (National Occupation and Employment Survey). The ENEO has surplanted the ENEU and the ENE (Encuesta Nacional de Empleo) since 2005. However, informal sector employment shares are available for the second trimester of every year using the ENEO methodology since 1995.
} 
employment rate. Informal sector employment fluctuated around an average value of $50 \%$ or $28 \%$ of the economically active population, respectively. Gasparini and Tornarolli (2009) corroborate this finding using both productive and legalistic definitions of informality as well as a self-employment share proxy using data from the ENIGH. ${ }^{14}$

Informal sector employment is mainly a phenomenon affecting unskilled workers. On average, $57 \%$ of all informal sector workers only have primary education or no formal education at all. Only $14 \%$ of informal sector employment represents individuals with an university degree, see the bottom panel in Figure 5. Finally, informal jobs tend to pay lower wages on average. Using a wage regression approach and a productive definition of informality, Gasparini and Tornarolli (2009) show that workers without secondary education have a 30\% lower hourly wage than their formal sector co-workers.

[Figure 1 about here.]

[Figure 2 about here.]

[Figure 3 about here.]

[Figure 4 about here.]

[Figure 5 about here.]

\section{The model}

Our model presents a unified treatment of the maquila phenomenon and informality using a heterogeneous firm model in the vein of Melitz (2003). Most of the informality literature has modeled the production side of the economy as populated by homogeneous firms which operate on perfectly competitive markets. However, empirical studies using firm-level data have highlighted the vast differences which exist across firms in terms of productivity, see e.g. Bernard and Jensen (1999). Furthermore, resource reallocations induced by an increase of foreign owned maquila plants occur not only across sectors as stressed by standard homogeneous firm trade models of the Heckscher-Ohlin type but also within industries from less productive firms to more productive ones. Crucially, firm-level adjustment processes work through the labor market and hence are important determinants for evaluating the labor market implications of the rise of the maquila sector. Standard homogeneous firm models are also intimately linked to perfect competition and hence the absence of firm profits. In heterogeneous firm models, fixed costs of entering export markets naturally give rise to operating profits. Therefore, foreign ownership of maquila plants can be cast quite naturally as profit repatriation. We merge the models of Bernard, Redding, and Schott (2007) and Felbermayr et al. (2011)

\footnotetext{
${ }^{14}$ Encuesta Nacional de Ingresos y Gastos de los Hogares, National Household Income and Spending Survey, collected by INEGI.
} 
to include the informal sector arising from search frictions into a multi-sector heterogeneous firm model of international trade. ${ }^{15}$

We treat Mexico as a small open economy and think of the US as the rest of world, abstracting from all other trade partners. This is not unduly restrictive, as $80 \%$ of all Mexican exports are shipped to the US. ${ }^{16}$ Thus, we only model Mexico explicitly and take the foreign price indices and expenditure shares as well as prices of the imported goods as given.

We assume that production in Mexico takes place in two sectors, maquila, $j=1$, and nonmaquila manufacturing, $j=2$, both populated by firms that are heterogeneous with respect to their productivity. ${ }^{17}$ There are two types of labor, skilled and unskilled, which are inelastically supplied by households, and we assume that Mexico is abundant in unskilled labor. Although workers of both types can move freely between sectors, we assume that the labor market for unskilled workers is subject to search and matching frictions as in Pissarides (2000). Firms pay a fixed cost to post vacancies for unskilled workers, and the filling rate of these vacancies depends on the aggregate tightness of the labor market. Individuals that do not get matched with firms in either of the two sectors earn an income in the informal sector. The labor market for skilled workers on the the other hand is assumed to be perfectly competitive in line with the near complete absence of high-skilled informal workers observed in the data.

\subsection{Consumption}

Mexican households only consume goods produced in the manufacturing sector, which means that maquila output is exported in its entirety. The representative consumer's utility takes the CES form,

$$
\begin{gathered}
U=C_{2}, \\
C_{2}=M_{2}^{\frac{1}{1-\sigma}}\left[\int_{\omega \in \Omega_{2 d}}\left[q_{2 d}(\omega)\right]^{\frac{\sigma-1}{\sigma}} d \omega+\int_{\omega^{\prime} \in \Omega_{2 f}}\left[q_{2 f}\left(\omega^{\prime}\right)\right]^{\frac{\sigma-1}{\sigma}} d \omega^{\prime}\right]^{\frac{\sigma}{\sigma-1}},
\end{gathered}
$$

where $C_{2}$ is a composite good from all different varieties produced in the manufacturing sector in Mexico, $\Omega_{2 d}$, and varieties imported from US, $\Omega_{2 f}, \sigma>1$ is the elasticity of substitution and $M_{2}$ denotes the total mass of varieties available in Mexico (including imported varieties). ${ }^{18}$ We follow Blanchard and Giavazzi (2003) and normalize utility by $M_{2}^{\frac{1}{1-\sigma}}$ in order to ensure that an increase of the size of an economy does not mechanically translate into a smaller informal sector.

Taking into account the existence of iceberg transportation costs $\tau_{2} \geq 1$ for imported

\footnotetext{
${ }^{15}$ For another heterogeneous firm model with search frictions on labor markets see Helpman and Itskhoki (2010).

${ }^{16}$ In $1991,79.4 \%$ of all exports were shipped to the US; in $2009,80.5 \%$.

${ }^{17}$ We will refer to the non-maquila manufacturing as manufacturing sector for short hereafter.

${ }^{18}$ The total number of manufacturing varieties available for consumption in Mexico is $M_{2}=M_{2 d}+M_{2 x}^{f}$ where $M_{2 x}^{f}$ denotes the mass of imported varieties.
} 
varieties, the price index corresponding to the composite $C_{2}$ is given by:

$$
P_{2}=M_{2}^{\frac{1}{\sigma-1}}\left[\int_{\omega \in \Omega_{2 d}}\left[p_{2 d}(\omega)\right]^{1-\sigma} d \omega+\int_{\omega^{\prime} \in \Omega_{2 f}}\left[\tau_{2} p_{2 f}\left(\omega^{\prime}\right)\right]^{1-\sigma} d \omega^{\prime}\right]^{\frac{1}{1-\sigma}} .
$$

Inverse demand for domestic and foreign varieties from sector 2 is then given by:

$$
\begin{aligned}
& p_{2 d}(\omega)=\left(\frac{Y}{M_{2}}\right)^{\frac{1}{\sigma}} P_{2}^{\frac{\sigma-1}{\sigma}} q_{2 d}(\omega)^{-\frac{1}{\sigma}}, \\
& p_{2 f}(\omega)=\left(\frac{\tau_{2} Y}{M_{2}}\right)^{\frac{1}{\sigma}} P_{2}^{\frac{\sigma-1}{\sigma}} q_{2 f}(\omega)^{-\frac{1}{\sigma}},
\end{aligned}
$$

where $Y$ denotes total expenditure in Mexico. Note that we define $p_{2 f}(\omega)$ as the cif price in the US and $q_{2 f}(\omega)$ is the total quantity produced, including the quantity lost in transit due to the iceberg transportation costs.

\subsection{Production}

Firms in both sectors are heterogeneous with respect to their idiosyncratic productivity, $\varphi$ as in Melitz (2003). Since each firm produces a unique variety, we index firm-level variables by $\varphi$.

\section{Manufacturing plants}

There is an unbounded mass of potential entrants in the domestic manufacturing sector. To enter, producers pay a sunk cost $f_{e 2}$. All fixed costs in the model, which include the fixed costs of entry, operation, exporting (only in sector 2) and vacancy posting are denominated in terms of units of the manufacturing good. Note that this implies that not all output produced can be used for consumption. Note also that this is contrary to Melitz (2003) where fixed costs are paid in terms of units of labor. This is not a viable option in our case as we will assume that there is bargaining between workers and employers where each worker is treated as the marginal one. When plant setup costs are effectively created by labor input, the bargaining power of unskilled workers would increase as they could prevent production from taking place altogether. After incurring this cost, firms draw their productivity from a Pareto distribution with density $g(\varphi)=a k^{a} \varphi^{-(a+1)}$ for $\varphi \geq k .^{19}$ Firms that choose to operate need to pay a fixed cost $f_{2}$ per period. Having setup the plant, manufacturing firms produce their output by combining skilled labor $s$ and unskilled labor $l$ in a Cobb-Douglas form,

$$
q_{2}(\varphi)=\varphi\left(s_{2}\right)^{\beta_{2 s}}\left(l_{2}\right)^{1-\beta_{2 s}}
$$

where $\beta_{2 s}$ is the labor cost share of skilled workers.

\footnotetext{
${ }^{19}$ We also restrict $a>\sigma-1$ to ensure that the variance of the sales distribution is finite.
} 
Firms sell their output domestically but can also incur an additional fixed cost $f_{x 2}$ to serve the foreign market through exports. We borrow the notion of a small open economy in a monopolistic competition environment from Flam and Helpman (1987), and the extension to a heterogeneous-firm environment proposed by Demidova and Rodríguez-Clare (2009). This assumption implies that, despite the fact that firms located in Mexico (both maquiladoras and manufacturing firms) face a downward-sloping demand schedule for their exports in the foreign market, their pricing decision does not affect the respective price index abroad. Demidova and Rodríguez-Clare (2011) show that this concept of a small country is the limit case of a large country model where the labor endowment share of the small country goes to zero. We also take as given the mass of foreign manufacturing firms and foreign demand for Mexican manufacturing goods but the subset of firms exporting to Mexico, $M_{2 x}^{f}$, is endogenous. ${ }^{20}$ Thus, inverse demand for Mexican manufacturing exports abroad is given by

$$
p_{2 x}(\varphi)=A_{2 x}^{1 / \sigma}\left(\frac{q_{2 x}(\varphi)}{\tau_{2}}\right)^{-\frac{1}{\sigma}}
$$

where $A_{2 x}$ is a demand parameter that is taken as given by Mexican manufacturing firms. Hence we can define total revenue for a Mexican manufacturing firm as:

$$
\begin{aligned}
r_{2}(\varphi) & =r_{2 d}(\varphi)+\mathbb{I}_{x}(\varphi) r_{2 x}(\varphi) \\
& =\left(\frac{Y}{M_{2}}\right)^{\frac{1}{\sigma}} P_{2}^{\frac{\sigma-1}{\sigma}} q_{2 d}(\varphi)^{\frac{\sigma-1}{\sigma}}+\mathbb{I}_{x}(\varphi) A_{2 x}^{1 / \sigma}\left(\frac{q_{2 x}(\varphi)}{\tau_{1}}\right)^{\frac{\sigma-1}{\sigma}},
\end{aligned}
$$

where $\mathbb{I}_{x}(\varphi)$ is an indicator function that takes the value one if a manufacturing firm with productivity $\varphi$ exports and zero otherwise.

\section{Maquiladora plants}

We model maquiladoras in a similar fashion to manufacturing firms, thus in this section we just highlight the differences between the two sectors, namely that (i) maquila plants are foreignowned, (ii) export all their output and (iii) use foreign manufacturing goods as intermediate inputs for production.

A foreign investor pays a sunk entry cost in Mexico (denominated in units of the Mexican manufacturing good) to set up a maquiladora plant. ${ }^{21}$ Productivity draws for maquiladoras are drawn from the same Pareto distribution as that for Mexican manufacturing firms. Since maquila output is assumed to be completely sold to US consumers, maquiladoras export all

\footnotetext{
${ }^{20}$ In both Flam and Helpman (1987) and Demidova and Rodríguez-Clare (2009) an endogenous variable that clears the balanced trade condition is needed. In Flam and Helpman (1987) firms from the small economy do not affect the expenditure level in the differentiated good abroad but can influence the price index. In Demidova and Rodríguez-Clare (2009), the price index and expenditure abroad are unaffected by Mexican firms but the share of US firms exporting to Mexico is endogenous. The choice of which variable to adjust to achieve equilibrium in the balance of payments is immaterial for our results.

${ }^{21}$ The fixed costs associated with the operation of the plant and vacancy posting for unskilled workers are also incurred in Mexico and are denominated in units of the Mexican manufacturing good.
} 
their output. Hence for maquiladoras, "...plant entry and exit is the same as the exporting decision" (Bergin et al., 2009, pp. 1669). This implies that there is no meaningful distinction between domestic and exporting fixed costs.

Finally, we assume that maquiladoras use foreign manufacturing goods as intermediate inputs, denoted by $i$, for production along with skilled and unskilled labor. Thus, production of maquila output for a plant with productivity $\varphi$ takes the form

$$
q_{1}(\varphi)=\varphi\left(s_{1}\right)^{\beta_{1 s}}\left(l_{1}\right)^{\beta_{1 l}}\left(i_{1}\right)^{1-\beta_{1 s}-\beta_{1 l}}
$$

where $\beta_{1 s}$ and $\beta_{1 l}$ is the skilled-labor and unskilled labor cost share for maquilas, respectively.

Inverse demand for maquila output abroad for variety $\varphi$ is given by,

$$
p_{1 x}(\varphi)=A_{1 x}^{1 / \sigma}\left(\frac{q_{1 x}(\varphi)}{\tau_{1}}\right)^{-\frac{1}{\sigma}},
$$

where $A_{1 x}$ is a foreign demand shifter that maquiladora plants take as given and has a similar interpretation to $A_{2 x}$ defined above. Total revenues for a maquiladora plant with productivity $\varphi$ are given by:

$$
r_{1}(\varphi)=r_{1 x}(\varphi)=A_{1 x}^{1 / \sigma}\left(\frac{q_{1 x}(\varphi)}{\tau_{1}}\right)^{\frac{\sigma-1}{\sigma}} .
$$

Unlike Mexican-owned plants in the manufacturing sector, profits derived from the operation of maquila plants are repatriated abroad.

\subsection{Labor market}

As discussed above, since most workers employed in the informal sector are unskilled, we assume that the search and matching frictions only affect these workers, whereas skilled workers face a perfectly competitive labor market. This means that in our model only unskilled workers are employed in the informal sector. Although we recognize that there are several ways in which informality can be incorporated into a search and matching framework, we argue that it is perfectly plausible that informational frictions play a prominent role in the labor market for low-skill occupations. ${ }^{22}$

Following Satchi and Temple (2009), unskilled individuals that are unable to get matched with a plant in the formal sector (either a manufacturing or maquila plant) end up as informal workers. These individuals earn income $b w_{l}$, with $b \in(0,1)$, financed by lump-sum transfers (charitable givings) from employed individuals, so we can interpret $1-b$ as the formality wage premium for unskilled workers.

\footnotetext{
${ }^{22}$ Assaad (1993) provides evidence of the importance of institutional arrangements based on group cohesion, kinship and social networking in regulating informal employment in the construction sector in Egypt. Topa (2001) finds that information exchange about job openings within social networks generate positive spillovers that are stronger for areas with less educated workers in Chicago. Similarly, Wahba and Zenou (2005) find that the importance of friends and relatives relative to other methods of finding a job is more important for uneducated individuals.
} 
Firms need to post vacancies $v$ to be filled by unskilled individuals which requires them to pay a fixed $\operatorname{cost} c$ per vacancy. As is common in the search and matching literature, we assume that the matching technology exhibits constant returns to scale, and takes a Cobb-Douglas form,

$$
m(\theta)=\bar{m} \theta^{-\gamma}, \quad \gamma \in(0,1),
$$

where $\theta \equiv v / u$ is the vacancy-informality ratio, and the parameter $\bar{m}$ determines the overall efficiency of the matching process in the economy. The probability that a vacancy is filled is given by $m(\theta)$, which is decreasing in $\theta$, and the probability that an unskilled individual in the informal sector finds a job in a formal plant is $\theta m(\theta)$ which is increasing in $\theta$.

As we focus on steady-state comparative statics, we follow Keuschnigg and Ribi (2009) and consider a simplified one-shot version of the search and matching framework. This has the additional advantage that it reduces the number of parameters to be calibrated in the next section. The only difference between the one-shot version and the textbook model as presented in Pissarides (2000) is that it assumes that the entire population of unskilled workers gets matched with firms in one period. ${ }^{23}$

The optimal labor demand decision for a manufacturing firm solves the following program:

$$
\pi_{2}(\varphi)=\max _{l_{2}, s_{2}}\left\{r_{2}(\varphi)-w_{l} l_{2}-w_{s} s_{2}-c P_{2}\left(\frac{l_{2}}{m(\theta)}\right)-f_{2} P_{2}-f_{x 2} \mathbb{I}_{x}(\varphi)\right\}
$$

subject to equation (6) and $q_{2}(\varphi)=q_{2 d}(\varphi)+\mathbb{I}_{x}(\varphi) q_{2 x}(\varphi)$, where we have also made use of the fact that a manufacturing plant wishing to hire $l_{2}$ unskilled workers needs to post $l_{2} / m(\theta)$ vacancies. $^{24}$

The solution to program (11) yields two policy rules, one for skilled labor demand, which is the usual condition that the marginal revenue product of skilled labor has to be equal to the skilled wage, $w_{s}$, and a second one for unskilled employment that reads:

$$
\frac{\partial r_{2}(\varphi)}{\partial l}=w_{l}+\frac{\partial w_{l}}{\partial l_{2}}+\frac{c P_{2}}{m(\theta)}
$$

This equation shows that the optimal demand for unskilled labor equalizes its marginal revenue product to the expected marginal cost of hiring an unskilled worker, which consists of three terms: (i) the wage paid to the marginal worker, (ii) a monopsony effect that the firm internalizes as the hiring of a new worker affects the wage bargaining for inframarginal workers and (iii) expected recruitment costs.

\footnotetext{
${ }^{23}$ This setting allows us to avoid choosing parameter values for the exogenous rate of match destruction and the exogenous failure rate of firms which would appear in the benchmark search and matching model. The qualitative results of our analysis remain unchanged when allowing for exogenous job destruction and plant exit.

${ }^{24}$ The labor demand program for maquila plants is almost identical to equation (11), with the only difference being that in addition, maquiladoras need to choose how much foreign intermediate inputs to use for production.
} 


\section{Wages}

As in Stole and Zwiebel (1996) we assume that unskilled workers bargain individually with their employers about their wage and are treated as the marginal worker. Total surplus of a worker-employer match is split according to a generalized Nash Bargaining solution:

$$
(1-\mu)[E(\varphi)-U]=\mu \frac{\partial \pi_{j}(\varphi)}{\partial l_{j}}, \quad j=1,2,
$$

where $E(\varphi)$ denotes the value of an unskilled worker employed at a plant with productivity $\varphi, U$ is the value of a worker in the informal sector, and $\mu \in(0,1)$ measures the bargaining power of a worker.

Following the same procedure as Felbermayr et al. (2011), i.e. combining the first-order conditions for unskilled employment by plants in both sectors together with the surplus-splitting rule (13), yields a set of two job-creation conditions (one for each sector):

$$
\begin{aligned}
& w_{l}+\frac{c P_{2}}{m(\theta)}=\left[\frac{\beta_{1 l}(\sigma-1)}{\sigma+\beta_{1 l} \mu-\mu-\beta_{1 l} \sigma \mu}\right] \varphi A_{1 x} s_{1}(\varphi)^{\beta_{1 s}} i_{1}(\varphi)^{1-\beta_{1 s}-\beta_{1 l}} l_{1}(\varphi)^{\beta_{1 l}-1} \\
& w_{l}+\frac{c P_{2}}{m(\theta)}=\left[\frac{\left(1-\beta_{2 s}\right)(\sigma-1)}{\sigma+\beta_{2 s} \mu-\mu-\beta_{2 s} \sigma \mu}\right] \varphi p_{2 d}(\varphi)\left(\frac{s_{2}(\varphi)}{l_{2}(\varphi)}\right)^{\beta_{2 s}} .
\end{aligned}
$$

The wage curve is given by:

$$
w_{l}=\frac{\mu c P_{2}}{(1-\mu)(1-b)}\left[\theta+\frac{1}{m(\theta)}\right] .
$$

Note that the job creation curves are downward sloping in the $\left(w_{l}, \theta\right)$ space and that the wage curve is upward sloping.

\subsection{Productivity cutoffs and entry}

As described in Section 3.2, the production side in our model closely follows Melitz (2003) and Bernard et al. (2007). Because $r_{j}(\varphi)$ is a strictly increasing function of $\varphi$, only plants with idiosyncratic productivity high enough to make non-negative profits will start production. Thus the usual productivity cutoff for production in sector $j$ is defined implicitly by $\pi_{j}\left(\varphi_{j}^{*}\right)=0$. In the manufacturing sector, where plants need to incur a fixed cost to serve the foreign market, an export cutoff is similarly defined as $\pi_{2 x}\left(\varphi_{2 x}^{*}\right)=0$. In the calibration exercise, the fixed costs of operation and exporting will be such that $\varphi_{2}^{*}<\varphi_{2 x}^{*}$, so the model produces selection into exporting.

We follow Melitz (2003) and define average productivity for maquiladoras and manufacturing firms as:

$$
\tilde{\varphi}_{j} \equiv\left[\frac{1}{1-G\left(\varphi_{j}^{*}\right)} \int_{\varphi_{j}^{*}}^{\infty} \varphi^{\sigma-1} g(\varphi) d \varphi\right]^{\frac{1}{\sigma-1}}, \quad j=1,2
$$


and the average productivity for manufacturing exporters,

$$
\tilde{\varphi}_{2 x} \equiv\left[\frac{1}{1-G\left(\varphi_{2 x}^{*}\right)} \int_{\varphi_{2 x}^{*}}^{\infty} \varphi^{\sigma-1} g(\varphi) d \varphi\right]^{\frac{1}{\sigma-1}}
$$

Finally, let $\chi_{2} \equiv\left[1-G\left(\varphi_{2 x}^{*}\right)\right] /\left[1-G\left(\varphi_{2}^{*}\right)\right]$ denote the ex-ante probability that a manufacturing plant exports, conditional on successful entry. Using these definitions we can write the freeentry condition for plants in sector $j$ as: ${ }^{25}$

$$
\left[1-G\left(\varphi_{j}^{*}\right)\right] \bar{\pi}_{j}=f_{e j} P_{2}, \quad j=1,2
$$

\subsection{Aggregate variables}

The equilibrium share of informal workers in the labor force follows from the one-period equivalent of the Beveridge curve and is given by:

$$
u=\frac{1}{1+\theta m(\theta)} .
$$

The mass of firms operating in sector $j$ in Mexico, $M_{j d}$, is pinned down by the unskilled labor market equilibrium:

$$
\begin{gathered}
M_{1 d}=\frac{L_{1}}{l_{1}\left(\tilde{\varphi}_{1}\right)}, \\
M_{2 d}=\frac{L_{2}}{l_{2 d}\left(\tilde{\varphi}_{2}\right)+\chi_{2} l_{2 x}\left(\tilde{\varphi}_{2 x}\right)},
\end{gathered}
$$

with $L_{1}+L_{2}=(1-u) \bar{L}$, where $L_{j}$ denotes total unskilled employment in sector $j$ and $\bar{L}$ is the total endowment of unskilled labor in the economy. Market clearing for skilled labor is given by,

$$
M_{1 d} s_{1}\left(\tilde{\varphi}_{1}\right)+M_{2 d}\left[s_{2 d}\left(\tilde{\varphi}_{2}\right)+\chi_{2} s_{2 x}\left(\tilde{\varphi}_{2 x}\right)\right]=\bar{S}
$$

The unskilled labor market is in equilibrium when the job creation conditions and the wage curve hold simultaneously.

Finally, the trade balance condition reads:

$$
\begin{gathered}
\underbrace{M_{1 d} r_{1}\left(\tilde{\varphi}_{1}\right)}_{\text {value of maquila exports }}+\underbrace{\chi_{2} M_{2 d} r_{2 x}\left(\tilde{\varphi}_{2 x}\right)}_{\text {value of manufacturing exports }}= \\
\underbrace{\tau_{2}^{1-\sigma}\left(\frac{Y}{M_{2}}\right)\left(\frac{P_{2}}{P_{2}^{f}}\right)^{\sigma-1}}_{\text {value of manufacturing imports }}+\underbrace{\tau_{2} P_{2}^{f} M_{1 d} i_{1}\left(\tilde{\varphi}_{1}\right)}_{\text {value of intermediate imports }}+\underbrace{M_{1 d} \pi_{1}\left(\tilde{\varphi}_{1}\right)}_{\text {aggregate maquila profits }}
\end{gathered}
$$

That is, on the left-hand side, the total value of exports in both sectors has to be equal to the sum of imports of foreign manufacturing goods used for domestic consumption and as

\footnotetext{
${ }^{25}$ Note that for maquiladoras, $\bar{\pi}_{1}=\pi_{1}\left(\tilde{\varphi}_{1}\right)$ and for manufacturing plants, $\bar{\pi}_{2}=\pi_{2 d}\left(\tilde{\varphi}_{2}\right)+\chi_{2} \pi_{2 x}\left(\tilde{\varphi}_{2 x}\right)$.
} 
intermediate inputs in maquiladoras, plus aggregate profits from maquila production which are repatriated to the US. We define the foreign price index for manufacturing goods, $P_{2}^{f}$, as the numéraire. Note that aggregate profits in the manufacturing sector remain in the home economy as it is domestically owned.

\section{Bringing the model to the data}

We calibrate parameters in order to match observations both at the aggregate and at the cross-section level for the Mexican economy. ${ }^{26}$ Table 1 presents the parameters used in the benchmark solution of the model.

[Table 1 about here.]

We set the vector of labor endowments to match the shares of empleados (non-production workers) and obreros (production workers) in the Mexican manufacturing sector. Thus $\bar{L} /(\bar{L}+$ $\bar{S})=0.825$. Since production in both sectors is assumed to take a Cobb-Douglas form, we use Sistema de Cuentas Nacionales de México (Mexican National Accounts System) data published by INEGI to calibrate the factor shares in each sector $\left\{\beta_{j k}\right\}_{j=1,2}^{k=s, l}$. To be consistent with our model, we take the gross value of production in the maquila sector to be composed of wage payments and consumption of foreign intermediate goods, which yields $\beta_{1 l}=0.089$, $\beta_{1 s}=0.028$ and $\beta_{1 i}=1-\beta_{1 l}-\beta_{1 s}=0.884$. In the manufacturing sector, the gross value of production is entirely accounted for by wage payments, resulting in $\beta_{2 l}=0.571$ and $\beta_{2 s}=$ $1-\beta_{2 l}=0.429$. Thus, $\beta_{2 s} / \beta_{2 l}>\beta_{1 s} / \beta_{1 l}$, which means that production of non-maquila manufacturing is relatively more skill-intensive than maquila production.

Since, as Satchi and Temple (2009) note, there are no studies that estimate search and matching models for Mexico, we choose to set both the elasticity of the matching function, $\gamma$, and the bargaining power of unskilled workers, $\mu$, at 0.5 , a common parametrization used in the calibration of search and matching models (Mortensen and Pissarides, 1994; Petrongolo and Pissarides, 2001; Albrecht et al., 2009; Felbermayr et al., 2011). The parameter $b$ that determines the income that unskilled workers earn while engaged in informal activities is pinned down by the estimate of a $29 \%$ formality premium for employees using data from Mexico's national survey of urban employment (ENEU) in Binelli and Attanasio (2010). ${ }^{27}$

The parameters characterizing the distribution from which both maquiladoras and manufacturing firms draw their productivity, the shape parameter $a$ and the lower bound of the support $k$, as well as the elasticity of substitution $\sigma$, are chosen following Bernard et al. (2007).

\footnotetext{
${ }^{26}$ Unless otherwise noted, all the figures correspond to the year 2000.

${ }^{27}$ Binelli and Attanasio (2010) calculate the formality premium as the ratio of mean formal to informal wages for male employees aged between 25 and 60. A worker is considered informal if he/she does not pay any social security contribution in either the private or the public sector. Based on their productive definition of informality, Gasparini and Tornarolli (2009) report a formality premium of $21.9 \%$ in Mexico for males with primary education, controlling for age and region, and a 30\% premium based on their legalistic definition. On average, for their sample of 19 Latin American countries, they find that informal male workers without a secondary education earn $30 \%$ less than their formal counterparts.
} 
Thus, $a=3.4, k=0.2$ and $\sigma=3.8$, satisfying the condition that $a>\sigma-1$, which insures that the variance of the sales distribution is finite. Note that we normalize the fixed entry costs of manufacturing plants $f_{e 2}$ to one. This allows us to interpret the matched magnitudes of the remaining fixed costs as multiples of $f_{e 2}$.

We set the iceberg transportation costs in both sectors $\left\{\tau_{j}\right\}_{j=1,2}$ at 1 , reflecting the fact that by $200187 \%$ of imports from Mexico entered the United States duty free, and the average duty on the remainder was $1.4 \%$, resulting in an overall average tariff rate of $0.2 \%$. Similarly, by 2001, after several rounds of unilateral trade liberalization and NAFTA provisions coming into place, around $93 \%$ of all manufacturing imports coming from the United States into Mexico paid duties under $5 \%$ and less than $1 \%$ of imports faced duties $10 \%$ or higher, resulting in an overall average Mexican tariff rate of 1.3\% (López-Córdova, 2003; Kose, Meredith, and Towe, 2004).

Ten parameters remain to be determined: The variety price of the average maquila firm, $p_{1 x}\left(\tilde{\varphi}_{1}\right)$, the cutoff price of the least productive manufacturing good exporter in the US, $p_{2 f}\left(\varphi_{2}^{* f}\right)$, the foreign demand parameters for the maquila and manufacturing sector, $A_{1 x}$ and $A_{2 x}$, respectively, the fixed cost of posting an unskilled vacancy, $c$, the efficiency level of the matching function, $\bar{m}$, the fixed entry cost associated with opening a maquiladora, $f_{1 e}$, the fixed cost of production in both sectors, $\left\{f_{j}\right\}_{j=1,2}$, and the fixed cost of exporting for manufacturing firms, $f_{x 2}$. The targets that we use to calibrate these parameters are the share of exporting firms in manufacturing (1), the average employment per establishment for the maquila (2) and manufacturing sector (3), aggregate trade openness (exports plus imports as a share of GDP) (4), the share of maquila exports in aggregate exports (5), the yearly transition probability from informal to formal employment (6), the share of workers employed in the informal sector (7), the maquila to GDP ratio (8), the intermediate imports to GDP ratio (9), and the ratio of Mexican to US GDP (10). ${ }^{28}$ Table 2 presents the set of moments that we target and their source.

To provide a better sense of how our model fits the data, we present equilibrium variables produced by our model that have not been directly calibrated. Since our model features a direct relationship between size (measured in terms of employment) and productivity, this implies that maquiladoras are the most productive firms in Mexico, being $15 \%$ more productive than local manufacturing exporters and $52 \%$ more productive than producers serving only the domestic market. Unfortunately since INEGI records plant-level variables for maquiladoras and non-maquiladora manufacturing plants in different surveys, to the best of our knowledge no study has yet compared the productivity performance of these two types of firms. Focusing on the manufacturing sector, our model predicts an exporter size premium of $43.5 \%$, which is very close to the $47.4 \%$ average reported by Verhoogen (2008) for Mexican manufacturing

\footnotetext{
${ }^{28}$ As we only model US demand for Mexican goods without specifying total US GDP, we relate the ratio of Mexican to US GDP to the ratio of Mexican manufacturing firms to US manufacturing exporting firms, i.e. we essentially assume that the mass of (exporting) firms operating in both countries is proportional to the total labor endowment following Chaney (2008). Note that in our model, we cannot separately identify the mass of US exporters from the total mass of US firms.
} 
plants for the period 1993-2001.

To compare the fixed costs of setting up and operating a plant in each sector, we scale them by average profits which also facilitates the comparison with other studies. Using this metric, our results indicate that the fixed cost of opening a maquiladora and the fixed cost of operation account for 21.7 and $33.0 \%$ of average sales respectively. The fixed costs paid by Mexican manufacturing firms are substantially smaller. Theoretical models where firms choose whether to serve foreign markets by exporting or opening a subsidiary as in Helpman, Melitz, and Yeaple (2004) and Antràs and Helpman (2004) assume that the fixed costs associated with FDI are larger than those of exporting. Entry and operation costs for firms operating only in the domestic market amount to $6.8 \%$ of total sales. Fixed costs of serving the foreign market by exporting are $1.6 \%$ of average export sales. The low estimates for the fixed cost of exporting are in line with structural estimates for Colombia reported by Das, Roberts, and Tybout (2007) and Ruhl and Willis (2008). Riaño (2009) structurally estimates the fixed costs of production and exporting for Mexican manufacturing firms in the second half of the 1980s to be around $33 \%$ of average labor costs and $5 \%$ of export sales revenues respectively. ${ }^{29}$ Finally, recruitment costs for the average Mexican manufacturing firm are on the order of $1.4 \%$ of its wage-bill (or $1.2 \%$ of its sales), a very close figure to that reported by Satchi and Temple (2009), who report vacancy costs of $1.2 \%$ of formal sector output in their model with homogeneous one-worker firms.

Our model has a harder time matching aggregate labor outcomes. The skill premium implied by our model, which is the wage of skilled workers relative to unskilled workers employed in the formal sector, is 1.7, whereas in the data, the average wage of non-production workers relative to production workers in the Mexican manufacturing sector is close to 2.7 in 2000 (Robertson, 2007). Our model also underestimates the maquila sector's share of manufacturing employment (3.5\% in our model versus $20 \%$ in the data). Although this result could be easily reversed if we allow the manufacturing sector to use intermediate inputs as well. Finally, our model produces a ratio of informal sector income to GDP of 0.22 which is higher than INEGI's own estimate of 0.13, although other studies such as Schneider and Enste (2000) estimate a much larger contribution of the informal sector relative to GDP, ranging between 0.40 to 0.60 in Mexico.

[Table 2 about here.]

\section{The rise of the maquiladoras during the nineties}

In order to obtain a quantitative assessment of the observed rise of the maquiladoras during the nineties, we use our model with the parameters obtained from the matching of moments and simulate a counterfactual increase of US demand for maquila goods. ${ }^{30}$

\footnotetext{
${ }^{29}$ In our model, fixed costs of domestic production correspond to $8 \%$ of the wage-bill for the average domestic manufacturing firm.

${ }^{30}$ Numerical solutions have gained importance for the analysis of international trade models in recent years, see e.g. Bernard, Eaton, Jensen, and Kortum (2003), Bernard et al. (2007), and Helpman and Itskhoki (2010).
} 
Specifically, we present two different counterfactual experiments: (i) An increase in the demand for maquila output abroad, and (ii) shutting down the informal sector by assuming that the labor market for unskilled workers is perfectly competitive.

In the first experiment we increase the foreign demand shifter for maquila goods, $A_{1 x}$, so as to produce an increase in the maquila sector's share of GDP from 4.2 to $9.9 \%$, which is what we observe in the rapid expansion of the maquila sector during the 1990s. ${ }^{31}$

To evaluate the welfare implications of the expansion of the maquila sector and the shutdown of the informal sector, we need a welfare measure which is comparable across the different counterfactual situations. Note that in our model, quantities consumed are strictly lower than quantities produced as fixed costs are paid in terms of the final manufacturing good. Therefore we resort to the real wage income as our welfare measure. As we assume homothetic preferences and given that the informal sector income is a lump sum transfer from formal sector workers, the appropriate welfare measure for Mexico in our model is given by real factor income

$$
W=\frac{(1-u) w_{l} \bar{L}+w_{s} \bar{S}}{P_{2}^{H}} .
$$

Because maquiladoras export all their output by definition, their decision of whether to operate or not is characterized by just one productivity cutoff, above which it is profitable for a firm to produce and export, instead of the usual two cutoffs (for domestic production and exporting) featured in trade models with firm heterogeneity. Moreover, because we assume that a firm's productivity is drawn from a Pareto distribution, the production cutoff for maquiladoras is given by:

$$
\varphi_{1}^{*}=k\left[\left(\frac{\sigma-1}{a-\sigma+1}\right)\left(\frac{f_{1}}{f_{1 e}}\right)\right]^{\frac{1}{a}} .
$$

Thus, an increase in the demand for maquila output from abroad will not affect the production cutoff in this sector. The increase in the demand for maquila will lead to an adjustment at the extensive margin, i.e. the number of firms, but not the intensive margin, i.e. the size of the firms. This contrasts with the usual result in heterogeneous firm models, in which increasing the profitability of exporting (by reducing iceberg transportation costs, for instance) produces within-sector reallocation of resources from low to high-productivity firms. Note that the exporting decision and the endogenous adjustment of productivity cutoffs is directly linked to consumer decisions. If we were to allow Mexican consumers to additionally consume the maquila good, productivity cutoffs would be endogenous but not all maquiladora plants would export.

Because the production cutoff in the maquila sector remains unchanged, our model leads to a one-to-one increase in both the mass of maquiladora firms and the value of maquila exports, both increasing by a factor of 2.3 for an increase of maquila demand of US from 0.6 to 1.4 times the value used for our benchmark calibration as can be seen in the upper left

\footnotetext{
${ }^{31}$ This involves increasing $A_{1 x}$ from 0.6 to 1.4 times the value used for our benchmark calibration.
} 
panel of Figure $6 .{ }^{32}$ In the manufacturing sector, however, the cutoff for domestic production falls, and the exporting cutoff increases which leads to a slight fall in average productivity in manufacturing of $0.1 \%$. How does this expansion of the maquila sector affect labor market outcomes in Mexico?

The first thing to notice is that the vacancy-informality ratio $\theta$ decreases and that the wage for unskilled workers $w_{l}$ increases. Since the labor market for unskilled workers is unified, this means that in net the wage curve has to shift up and to the left, regardless of shifts in the job creation curve, otherwise we would not observe the negative correlation between $w_{l}$ and $\theta$. As manufacturing is substantially larger than the maquila sector (Manufacturing unskilled employment always accounts for more than $90 \%$ of the total unskilled labor force for all the values of the comparative statics exercise), the contraction in the manufacturing sector releases a lot of unskilled workers, many more than the maquiladora sector could potentially employ.

If we look at the wage curve given in Equation (16), remember that it is increasing in $\theta$ $\left(m^{\prime}(\theta)<0\right)$. Given that $\theta$ is decreasing, the only way that $w_{l}$ can increase is if $P_{2}$ increases more than what the term in square brackets (the one containing all the $\theta$ 's) falls. In the comparative statics exercise, $P_{2}$ increases by $3.1 \%$ brought about by the decrease in average manufacturing productivity whereas the whole term in square brackets falls by $2.4 \%$.

The skill premium decreases (upper right panel in Figure 6). As the maquila sector is unskilled labor-intensive, this result is as expected and follows from a standard Stolper-Samuelson argument. Hence our model is in line with the empirical evidence for the 1990s and presents an alternative mechanism which explains how an increase in offshoring activity affects the skill-premium. ${ }^{33}$

[Figure 6 about here.]

[Figure 7 about here.]

[Figure 8 about here.]

[Figure 9 about here.]

The size of the informal sector increases slightly as can be seen in the lower left panel of Figure 6. The reason for this behavior is due to the fact that all fixed costs including the vacancy posting cost are denominated in units of the manufacturing good, an expansion of the unskilled intensive maquila sector implies that Mexico spends relatively more on these costs which reduce the amount of manufacturing goods for final consumption. This effect outweighs the increase in the relative demand for unskilled workers.

In order to maintain equilibrium in the balance of payments, the larger trade surplus in the maquila sector needs to be balanced by a larger trade deficit in manufacturing. This is

\footnotetext{
${ }^{32}$ All percentage changes given in the following are for this change.

${ }^{33}$ See Feenstra and Hanson (1996) which document an increase in wage inequality after Mexico joined the GATT in 1986, and Robertson (2007) which documents the reverse pattern after the erection of NAFTA during the 1990s.
} 
achieved by a $6.9 \%$ increase in the mass of firms exporting manufacturing goods to Mexico from the US. This implies that there remains less manufacturing goods for consumption by Mexican consumers which is reflected in the fact the the Mexican price index increases.

Finally, overall welfare as measured by real factor income for both skilled and unskilled workers decreases by $3.7 \%$. The increase in unskilled wages of $0.6 \%$ is more than offset by the reduction of skilled wages by $2.1 \%$ and the increase in the price level which affects all workers equally.

In our second experiment, we counterfactually shut down the informal sector by assuming that both unskilled and skilled labor is hired on competitive labor markets. All the parameters remain equal. We then compare real factor income and the skill premium in both scenarios, see the left panel of Figure 7. Welfare is higher in the economy with an informal sector. This is due to the fact that unskilled workers cannot use the informal sector wage as an outside option in the bargaining process as they are simply paid their marginal value product in a perfectly competitive labor market. In the presence of an informal sector, workers will decline the job offered in the informal sector and start a business in the informal sector if the wage paid in the formal sector is too low. This threat of the exit option forces employers to pay more to their employees. Note that the welfare difference is large: For our calibration benchmark, real factor income is $33.5 \%$ lower when the informal sector is shut down. Finally, the skill premium is lower if there exists the informal sector. The reason is that all unskilled workers are forced to work in the formal sector which reduces the unskilled wage. Hence the informal sector effectively reduces inequality in Mexico. Our counterfactual analysis thus sheds a new light on the empirically observed positive correlation between inequality and informality (Chong and Gradstein, 2007).

In order to check whether welfare can be higher without an informal sector if the maquila sector increases enough, we counterfactually increase the demand parameter for maquila goods until Mexico essentially specialises completely in the production of maquila goods. This implies a 28-fold increase in the maquila demand parameter. We present the results in Figures 8 and 9. As can be seen in Figure 8, effects on the skill premium, the informal sector size as well as welfare remain the same across the whole parameter range. Only when the demand parameter for maquila goods increases by more than 17 times the value of our calibration exercise, welfare is higher in the economy without the informal sector than in the economy with frictions on the labor market. Only then the inefficiency arising due to the goods spent on the vacancy posting costs outweighs the advantage of the better bargaining position of unskilled workers. As our calibrated model only needs a 1.6-fold increase in the demand parameter to replicate the rise of the maquiladoras during the 1990s, the higher welfare level in the presence of the informal sector holds for any increase in US demand for maquila goods in the foreseeable future. 


\section{Conclusion}

This paper investigates the relationship between the rise of the maquila sector in Mexico, its linkages to informal sector employment as well as its broader implications for Mexican welfare. Hopes from politicians were that a large influx of foreign-capital, like the one induced by the maquiladoras program, would lead to greater welfare and a reduction of the informal sector in Mexico.

We calibrate key parameters of a heterogeneous firm model with imperfect labor markets in order to match key stylized facts of the Mexican economy- Using our calibrated model we evaluate the impact of an increase in the foreign demand for maquila output consistent with the observed expansion on the sector during the 1990s. We counterfactually evaluate that the empirically observed increase in the GDP share of maquila production during the 1990s leads to a decrease of the skill premium by $2.7 \%$, an increase of the informal sector by $0.9 \%$, and a decrease of welfare by $3.7 \%$.

Additionally, shutting down the informal sector in our model would decrease Mexican welfare by $33.5 \%$ as compared to a situation with an informal sector. The main reason is that this closes down the possibility of unskilled workers to switch to the informal sector when offered wages are low. In other words, the informal sector strengthens the bargaining power of unskilled workers, leading to a greater share of profits in the maquila sector to be payed out to Mexican workers.

Our results suggest that the presence of a large informal sector is not necessarily detrimental to Mexico's overall welfare, at least given the level of development and its general production and consumption structure. What is more, the reduction of informality creates a new distributional conflict between skilled and unskilled workers which has been overlooked both in the theoretical literature as well as in policy discussions so far. The results also indicate that labor market frictions may create intricate choices for policy makers as increasing formal sector employment and restricting access to informal jobs in order to increase tax revenues and payments to pension systems may well be detrimental to voters' welfare.

Although we have assumed away knowledge spillovers and input linkages between maquiladoras and domestic manufacturing firms, common elements in models studying vertical FDI, these can be easily incorporated into our framework. An interesting extension of our model could be used to understand how tributary incentives to increase the share of domestic inputs in the maquila supply chain affects the results in this paper.

Finally, as the focus of our analysis lies on evaluating the rise of the maquiladoras and their link to the informal sector we abstract from firm-level dynamics. The literature has recently shown that production in the maquiladora sector is very volatile. Hence a focus on the short-run adjustment dynamics of both the intensive and extensive margin of the maquila sector and their implications for informal sector employment seem to be a natural venue for future research. 


\section{References}

Albrecht, J., L. Navarro, and S. Vroman (2009): "The effects of labour market policies in an economy with an informal sector," Economic Journal, 119, 1105-1129.

Antràs, P. And E. Helpman (2004): "Global sourcing," Journal of Political Economy, 112, $552-580$.

AssaAD, R. (1993): "Formal and informal institutions in the labor market, with applications to the construction sector in Egypt," World Development, 21, 925-939.

Bergin, P. R., R. C. Feenstra, and G. H. Hanson (2009): "Offshoring and volatility: evidence from Mexico's maquiladora industry," American Economic Review, 99, 1664-1671.

Bernard, A. B., J. Eaton, J. B. Jensen, and S. Kortum (2003): "Plants and productivity in international trade," American Economic Review, 93, 1268-1290.

Bernard, A. B. And J. B. Jensen (1999): "Exceptional exporter performance: cause, effect, or both?" Journal of International Economics, 47, 1-25.

Bernard, A. B., S. J. Redding, And P. K. Schott (2007): "Comparative advantage and heterogeneous firms," Review of Economic Studies, 74, 31-66.

Binelli, C. And O. Attanasio (2010): "Mexico in the 1990s: the main cross-sectional facts," Review of Economic Dynamics, 13, 238-264.

Blanchard, O. And F. Giavazzi (2003): "Macroeconomic effects of regulation and deregulation in goods and labor markets," Quarterly Journal of Economics, 118, 879-907.

Boyenge, J.-P. S. (2007): "ILO database on export processing zones (revised)," ILO Working Paper 251.

Chandra, V. And M. A. Khan (1993): "Foreign investment in the presence of an informal sector," Economica, 60, 79-103.

Chaney, T. (2008): "Distorted gravity: the intensive and extensive margins of international trade," American Economic Review, 98, 1707-1721.

Chong, A. And M. Gradstein (2007): "Inequality and informality," Journal of Public Economics, 91, 159-179.

Das, S., M. J. Roberts, And J. R. Tybout (2007): "Market entry costs, producer heterogeneity, and export dynamics," Econometrica, 75, 837-873.

Demidova, S. And A. Rodríguez-Clare (2009): "Trade policy under firm-level heterogeneity in a small economy," Journal of International Economics, 78, 100-112. 
(2011): "The simple analytics of the Melitz model in a small open economy," NBER working paper 17521.

Feenstra, R. C. And G. H. Hanson (1996): "Foreign investment, outsourcing and relative wages," in The Political Economy of Trade Policy: Papers in Honor of Jagdish Bhagwati, ed. by R. Feenstra, G. Grossman, and D. Irwin, Cambridge: MIT Press, 89-127.

Felbermayr, G., J. Prat, And H.-J. Schmerer (2011): "Globalization and labor market outcomes: wage bargaining, search frictions, and firm heterogeneity," Journal of Economic Theory, 146, 39-73.

Flam, H. AND E. Helpman (1987): "Industrial policy under monopolistic competition," Journal of International Economics, 22, 79-102.

Gasparini, L. And L. Tornarolli (2009): "Labor informality in Latin America and the Caribbean: patterns and trends from household survey microdata," Desarollo y Sociedad, 13-80.

Gong, X., A. Van Soest, And E. Villagomez (2004): "Mobility in the urban labor market: a panel data analysis for Mexico," Economic Development and Cultural Change, $53,1-36$.

Graham, E. M. And E. Wada (2000): "Domestic reform, trade and investment liberalisation, financial crisis, and foreign direct investment into Mexico," World Economy, 23, $777-797$.

Helpman, E. And O. Itskhoki (2010): "Labour market rigidities, trade and unemployment," Review of Economic Studies, 77, 1100-1137.

Helpman, E., M. J. Melitz, and S. R. Yeaple (2004): "Export versus FDI with heterogeneous firms," American Economic Review, 94, 300-316.

IACOvone, L. AND B. S. JavorCIK (2010): "Multi-product exporters: product churning, uncertainty and export discoveries," Economic Journal, 120, 481-499.

ILO (1993): Resolution Concerning Statistics of Employment in the Informal Sector, Adopted by the Fifteenth International Conference of Labour Statisticians, Geneva: International Labor Organization (ILO).

Jütting, J. P. And J. R. DE LAiglesia, eds. (2009): Is informal normal? Towards more and better jobs in developing countries, Paris: OECD.

Kehoe, T. J. (1995): "A review of Mexico's trade policy from 1982 to 1994," in The World Economy: Global Trade Policy 1995, ed. by S. W. Arndt and C. R. Milner, Oxford and Cambridge: Blackwell, 135-151. 
KeuschnigG, C. And E. Ribi (2009): "Outsourcing, unemployment and welfare policy," Journal of International Economics, 78, 168-176.

Kose, M. A., G. Meredith, And C. M. Towe (2004): "How has NAFTA affected the Mexican economy? Review and evidence," in Monetary Policy and Macroeconomic Stabilization in Latin America, ed. by R. J. Langhammer and L. V. de Souza, Berlin, New York: Springer, 35-81.

LÓPEz-Córdova, E. (2003): "NAFTA and manufacturing productivity in Mexico," Economia: The Journal of the Latin American and Caribbean Economic Association, 4, 55-88.

Maloney, W. F. (1998): “Are labor markets in developing countries dualistic?" World Bank Policy Research Working Paper 1941.

(2004): "Informality revisited," World Development, 32, 1159-1178.

Marjit, S., S. Ghosh, And A. Biswas (2007): "Informality, corruption and trade reform," European Journal of Political Economy, 23, 777-789.

Martin, G. (2000): "Employment and unemployment in Mexico in the 1990s," Monthly Labor Review, 123, 3-18.

Melitz, M. J. (2003): "The impact of trade on intra-industry reallocations and aggregate industry productivity," Econometrica, 71, 1695-1725.

Mortensen, D. And C. Pissarides (1994): "Job creation and job destruction in the theory of unemployment," Review of Economic Studies, 61, 397-415.

Petrongolo, B. And C. A. Pissarides (2001): "Looking into the black box: a survey of the matching function," Journal of Economic Literature, 39, 390-431.

Pissarides, C. A. (2000): Equilibrium Unemployment Theory. Second Edition, Cambridge: MIT Press.

RAmirez, M. D. (2006): "Is foreign direct investment beneficial for Mexico? An empirical analysis, 1960-2001," World Development, 34, 802-817.

RiAÑO, A. (2009): "Trade, technology adoption and the rise of the skill premium in Mexico," University of Nottingham Working Paper.

Robertson, R. (2007): "Trade and wages: two puzzles from Mexico," The World Economy, 30, 1378-1398.

Ruhl, K. J. AND J. L. WiLlis (2008): "New exporter dynamics," Unpublished working paper.

SAtchi, M. And J. Temple (2009): "Labor markets and productivity in developing countries," Review of Economic Dynamics, 12, 183-204. 
Schneider, F. AND D. H. Enste (2000): "Shadow economies: size, causes, and consequences," Journal of Economic Literature, 38, 77-114.

Stole, L. A. And J. Zwiebel (1996): "Intra-firm bargaining under non-binding contracts," Review of Economic Studies, 63, 375-410.

Ulyssea, G. (2010): "Regulation of entry, labor market institutions and the informal sector," Journal of Development Economics, 91, 87-99.

Verhoogen, E. A. (2008): "Trade, quality upgrading, and wage inequality in the Mexican manufacturing sector," Quarterly Journal of Economics, 123, 489-530.

Villarreal, M. A. (2010): "NAFTA and the Mexican economy," Tech. rep., Congressional Research Service.

WahbA, J. And Y. Zenou (2005): "Density, social networks and job search methods: theory and application to Egypt," Journal of Development Economics, 78, 443-473.

WALDKIRCH, A. (2010): "The effects of foreign direct investment in Mexico since NAFTA," The World Economy, 33, 710-745.

Zenou, Y. (2008): "Job search and mobility in developing countries. Theory and policy implications," Journal of Development Economics, 86, 336-355. 


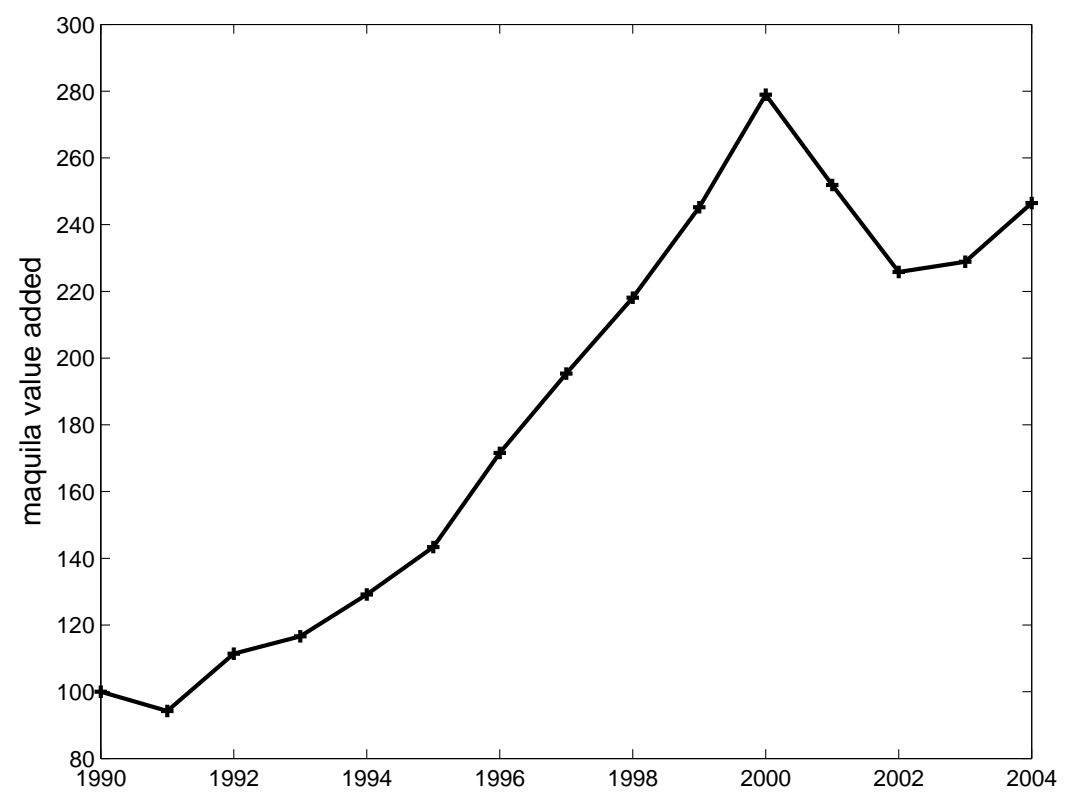

Note: This figure depicts the annual value added in the industria maquiladora de exportación in constant 1993 prices. We normalize the series by using 1990 as a base year. Source: INEGI, Sistema de Cuentas Nacionales de México (Mexican National Accounts System).

Figure 1: Maquila value added, 1990=100, 1990-2004 


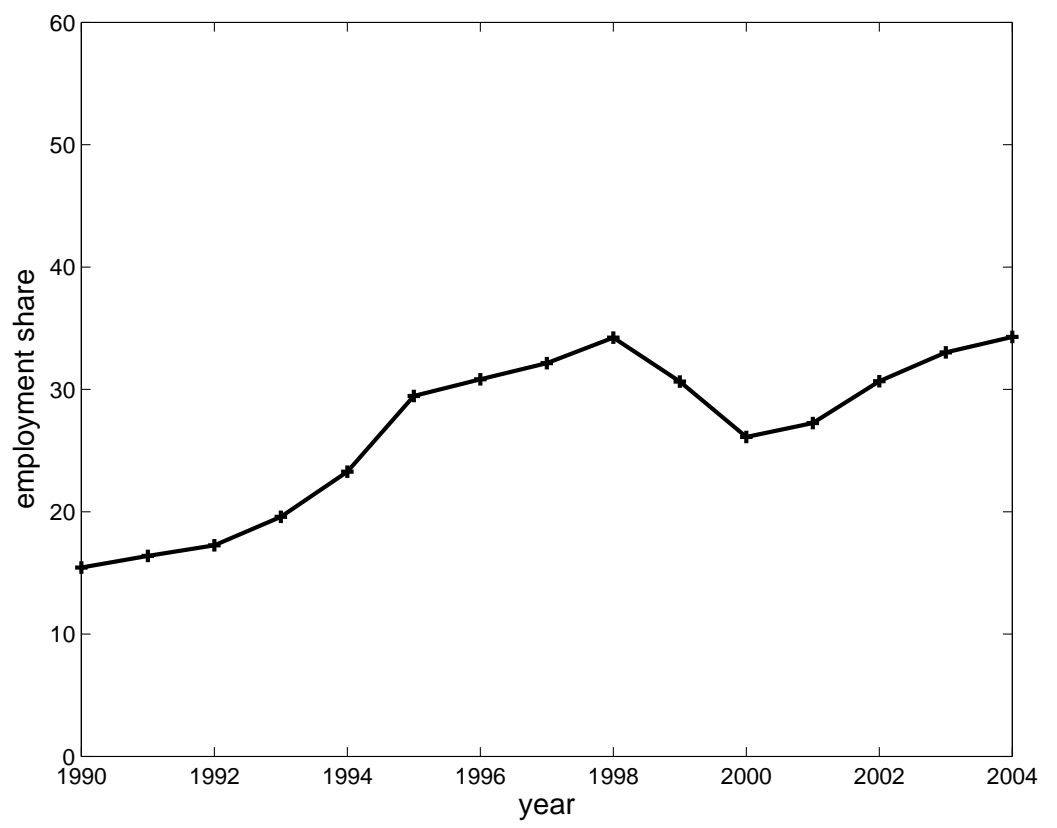

Note: This figure depicts the share of employment in the industria maquiladora de exportación as percentage of total manufacturing employment. Source: CNIME (Consejo Nacional de la Industria Maquiladora y Manufacturera de Exportación, National Council of Maquiladora Industries) with data from INEGI.

Figure 2: Share of maquila employment in total manufacturing employment, 1990-2004 


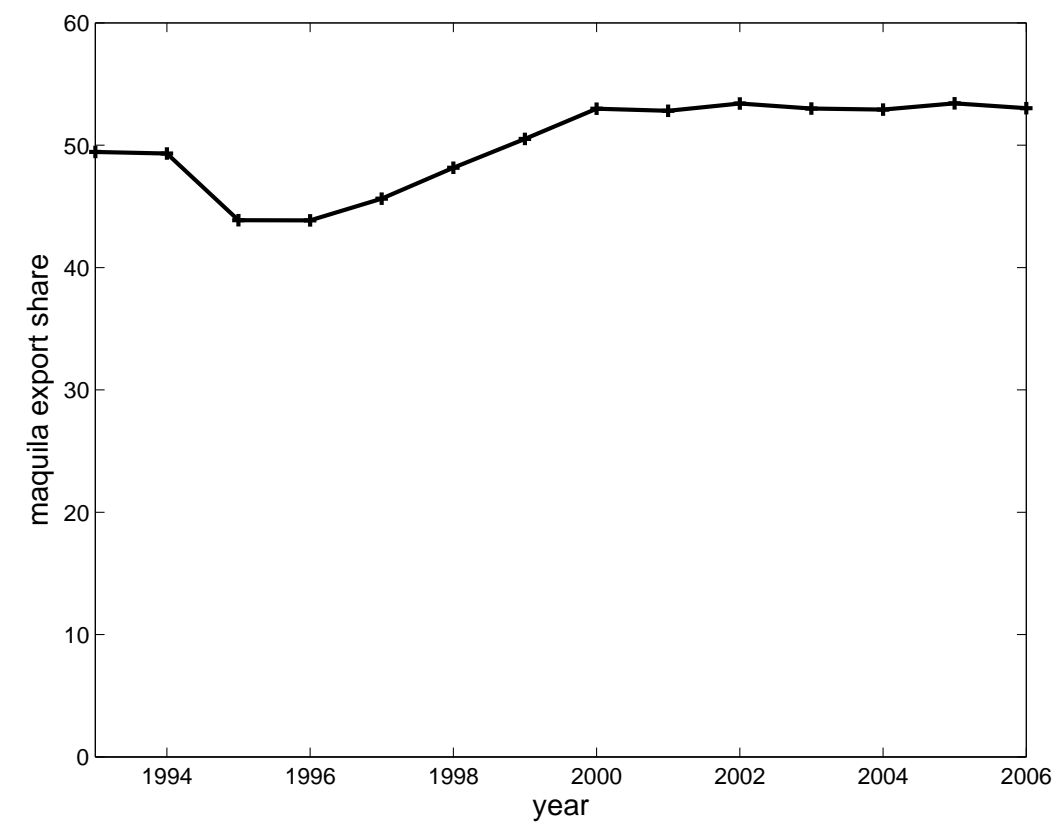

Note: This figure depicts the share of industria maquiladora de exportación exports as percentage of total Mexican non-petrol exports. Source: Banco de México.

Figure 3: Share of maquila exports in total exports, 1993-2006 


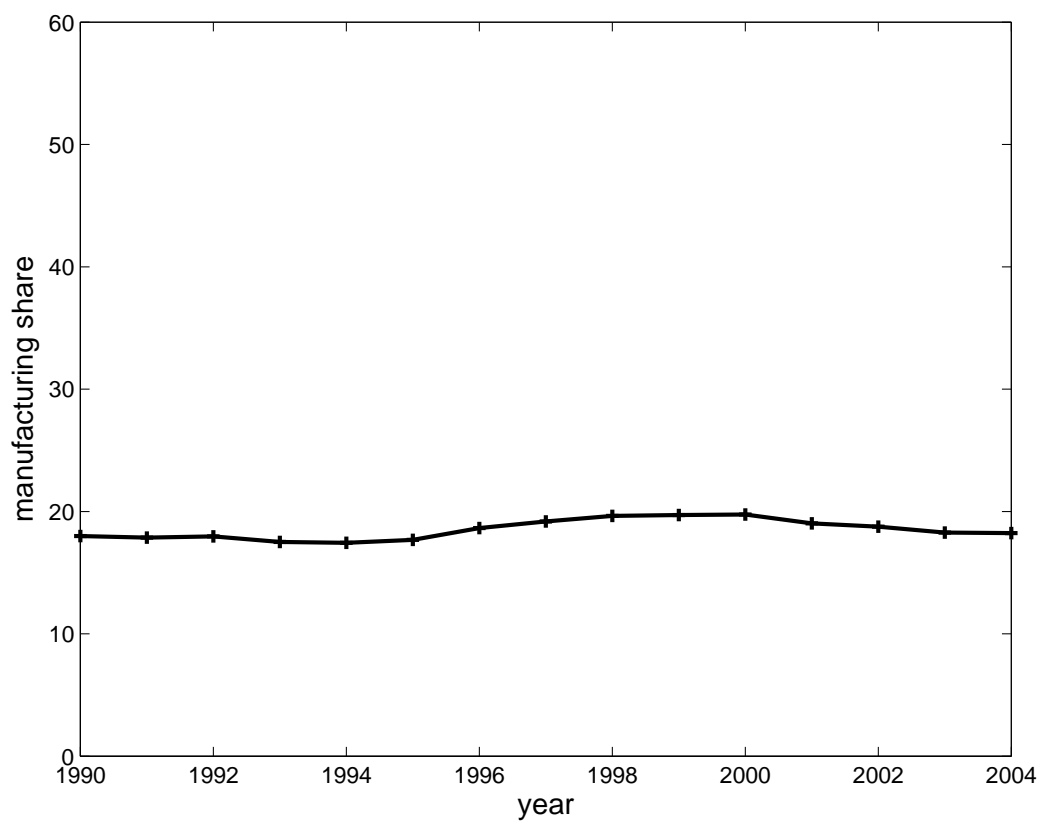

Note: This figure depicts the annual value added in total manufacturing as a share of Mexican GDP in constant 1993 prices. Source: INEGI, Sistema de Cuentas Nacionales de México (Mexican National Accounts System).

Figure 4: Share of total manufacturing in GDP, 1990-2004 

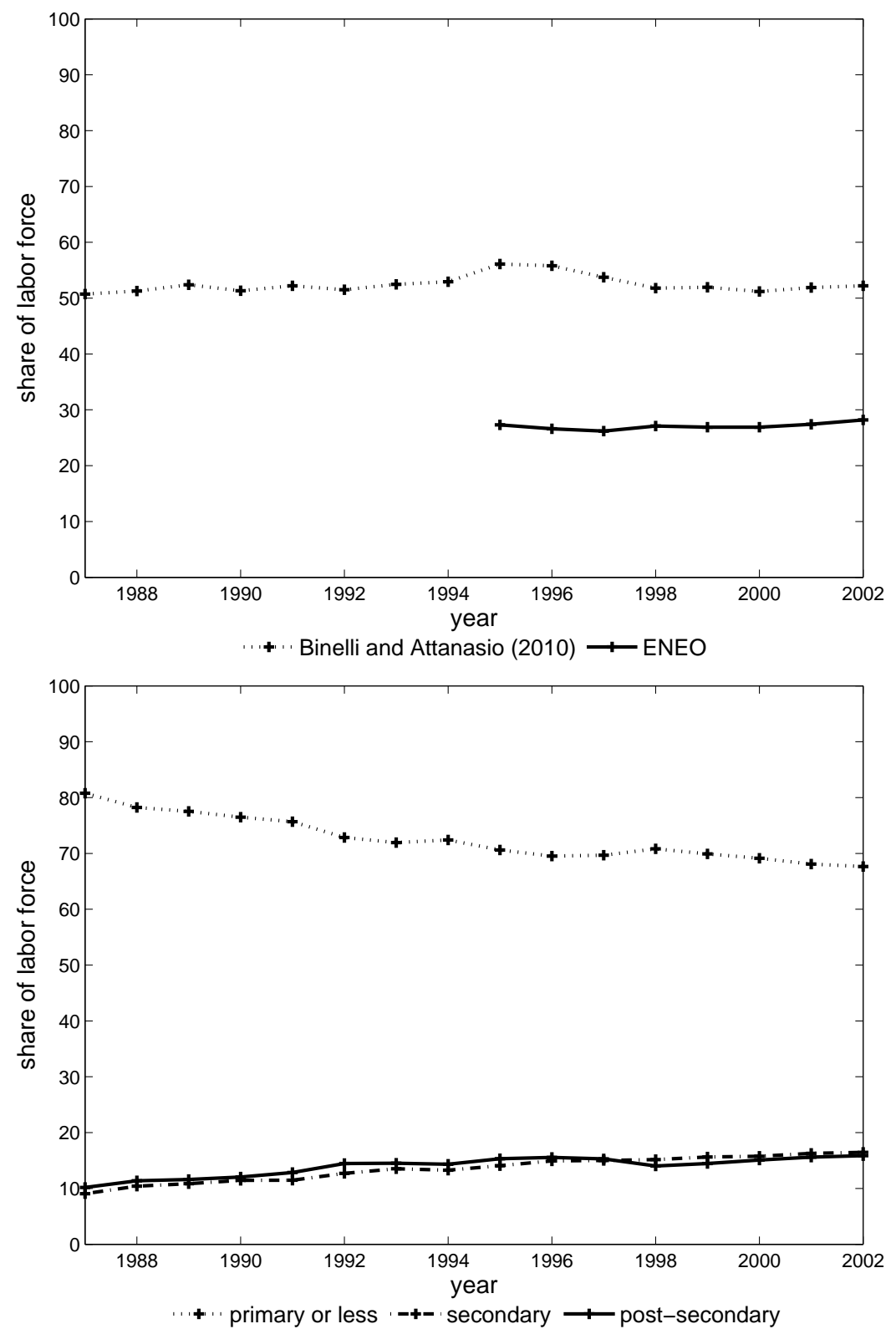

Note: The upper panel shows the share of informal workers for different definitions of the working age population. Binelli and Attanasio (2010) define it for individuals between age 25 and 60 using the ENEU (Encuesta Nacional de Empleo Urbano); official data published by INEGI define it for individuals between 14 and 98 using the ENEO. The ENEU series are computed on a yearly basis. The ENEO series depicts values for the second trimester of every year as this is the only information available from INEGI for the years 1995 to 1999. The lower panel shows the share of informal workers with different education levels from Binelli and Attanasio (2010) again using the ENEU data. Sources: INEGI, ENEO and Binelli and Attanasio (2010).

Figure 5: Informal sector employment share and educational attainment, 1987-2002 

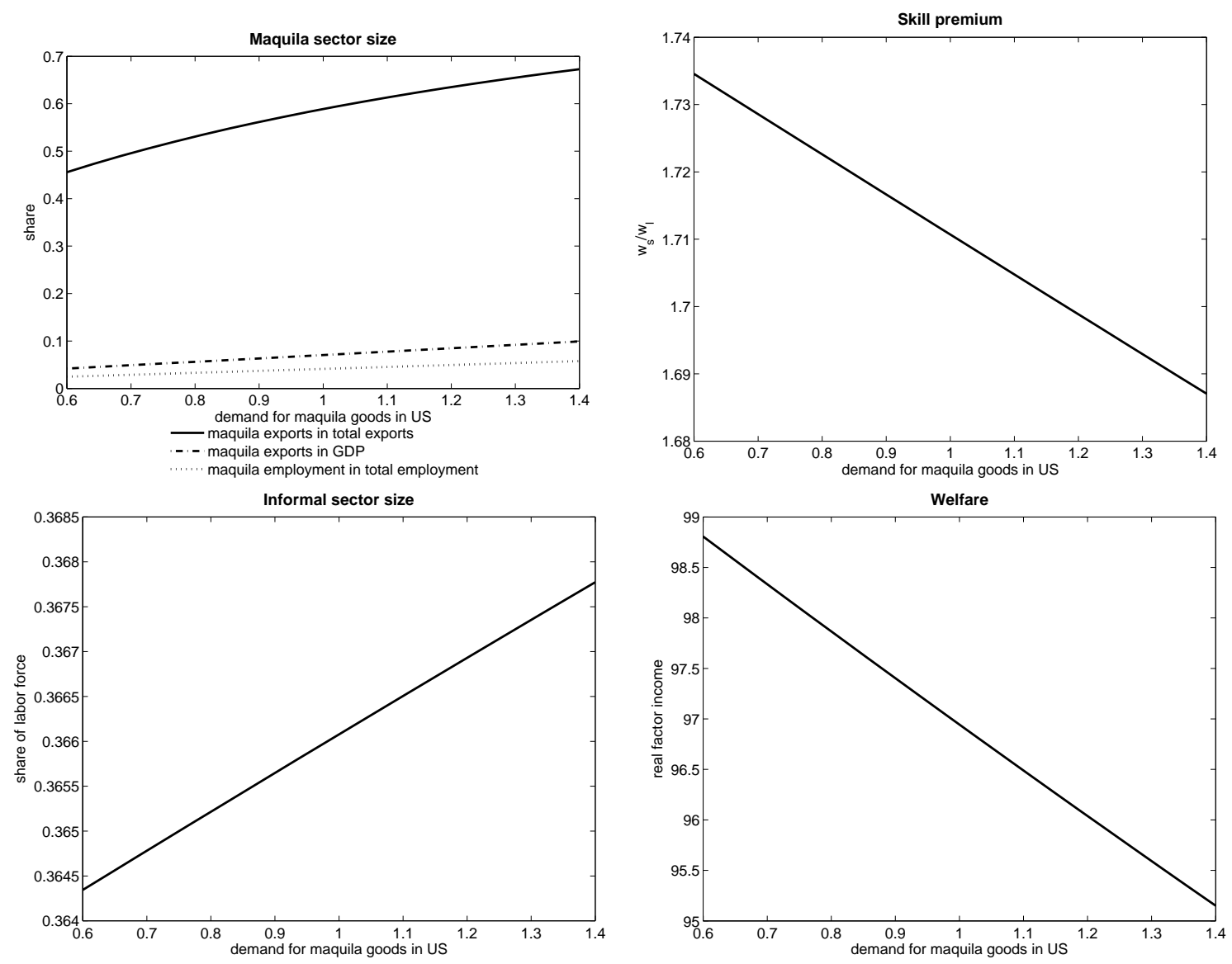

Figure 6: Comparative statics of demand in the maquila sector 

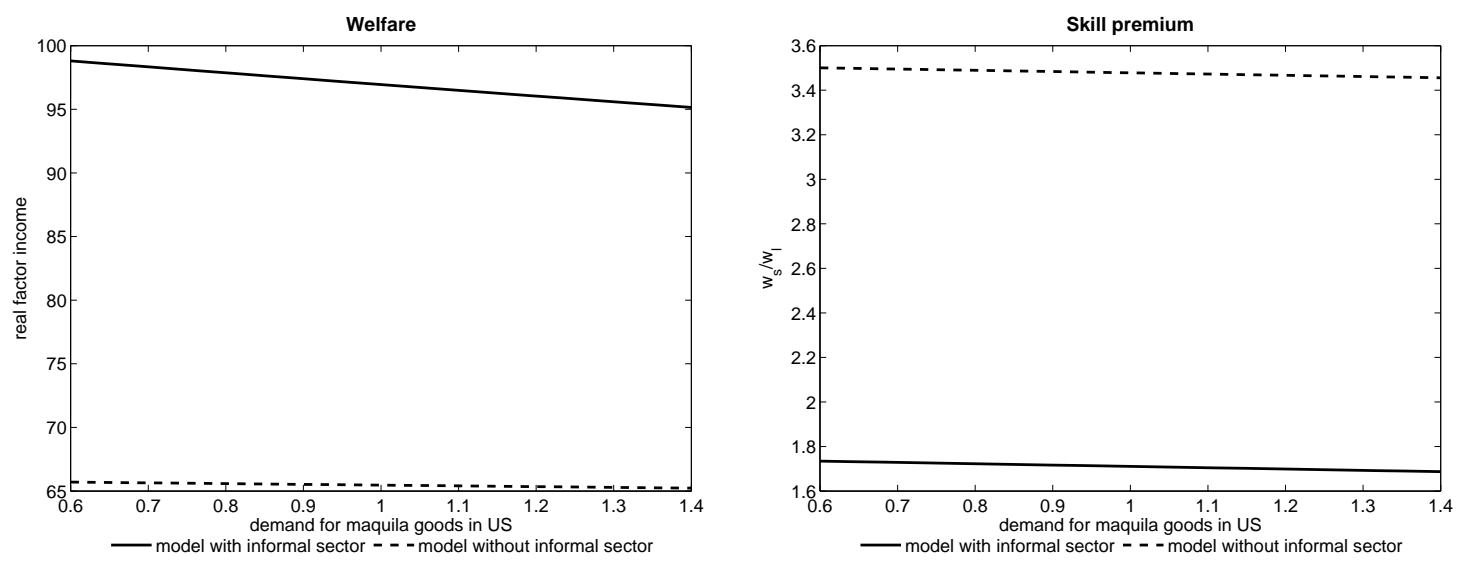

Figure 7: Counterfactual shutdown of informal sector 

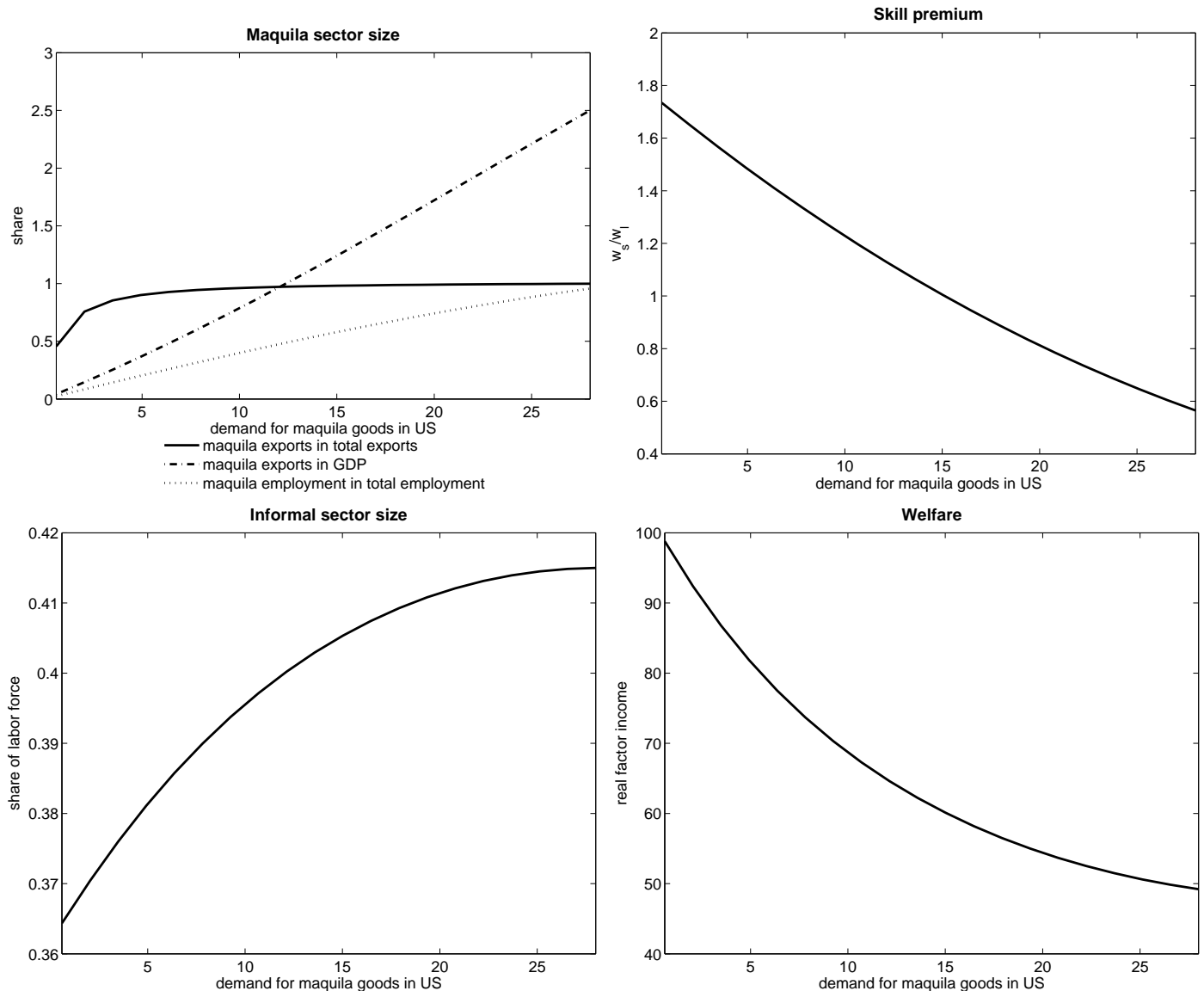

Figure 8: Comparative statics of demand in the maquila sector, part 2 

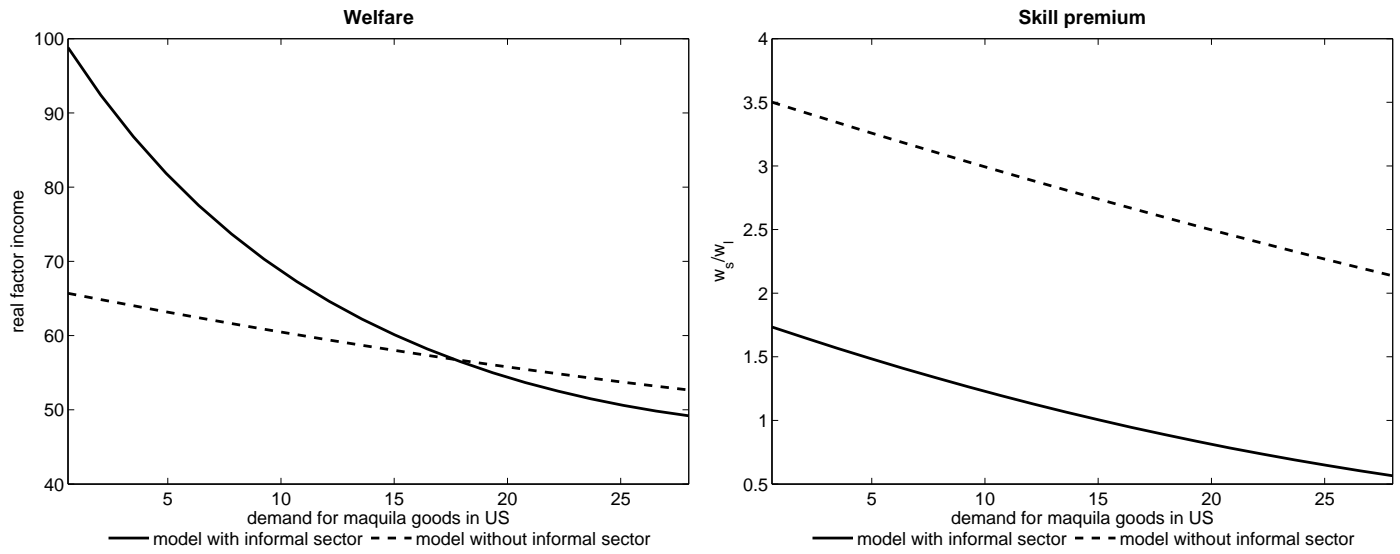

Figure 9: Counterfactual shutdown of informal sector, part 2 
Table 1: Parameters for the baseline economy

\begin{tabular}{llr}
\hline Parameter & Description & Value \\
\hline$\sigma$ & Elasticity of substitution & 3.800
\end{tabular}

Foreign market

$P_{2}^{f}$

$\mathbf{p}_{1 \mathrm{x}}\left(\tilde{\varphi_{1}}\right)$

$\mathbf{p}_{\mathbf{2 f}}\left(\varphi_{\mathbf{2}}^{* \mathbf{f}}\right)$

$\mathrm{A}_{1 \mathrm{x}}$

$\mathrm{A}_{2 \mathrm{x}}$

Labor market

$\bar{L}$

$\bar{S}$

$\mu$

$\gamma$

$1-b$

c

$\overline{\mathbf{m}}$

Factor shares

$\beta_{1 l}$

$\beta_{1 s}$

$\beta_{1 i}$

$\beta_{2 l}$

$\beta_{2 s}$

\section{Productivity distribution}

a

$k$

Transport costs

$\left\{\tau_{j}\right\}_{j=1,2}$

Iceberg transportation costs in sector $j$

Unskilled labor endowment

Skilled labor endowment

Bargaining power unskilled workers

Matching function elasticity

Formality premium

Vacancy posting fixed cost

Efficiency of matching function

Unskilled labor share maquila

0.089

Skilled labor share maquila

0.028

Foreign intermediates share maquila

0.884

Unskilled labor share manufacturing

0.571

Skilled labor share manufacturing

0.429

Pareto distribution shape parameter

Pareto distribution lower bound

0.200

1.000

\section{Fixed costs}

$f_{e 2}$

$f_{\mathrm{e} 1}$

$\mathrm{f}_{1}$

$f_{2}$

$f_{x 2}$
Fixed entry cost manufacturing

Fixed entry cost maquila

Fixed cost of production maquila

Fixed cost of production manufacturing

Fixed cost of exporting manufacturing
42.266

64.264

0.311

0.135

Note: Parameters in bold are chosen to match calibration targets defined in Table 2. 
Table 2: Calibration targets

\begin{tabular}{rlc}
\hline \# & Statistic to match & Target \\
\hline 1 & Share of exporters, manufacturing & 0.389 \\
2 & Mean plant size, maquila & 371 \\
3 & Mean plant size, manufacturing & 214 \\
4 & Aggregate trade openness & 0.600 \\
5 & Share of maquila exports in total exports & 0.549 \\
6 & Yearly transition rate informal $\rightarrow$ formal & 0.210 \\
7 & Share of informal workers & 0.366 \\
8 & Maquila value added to GDP ratio & 0.093 \\
9 & Intermediate imports to GDP ratio & 0.106 \\
10 & Mexican to US GDP ratio & 0.091 \\
\hline
\end{tabular}

Note: The share of exporting plants (1) comes from Iacovone and Javorcik (2010). The mean size of maquila plants (2) come from CNIME (Consejo Nacional de la Industria Maquiladora y Manufacturera de Exportación, National Council of Maquiladora Industries). Mean plant size for manufacturing (3) is from INEGI, EIA (Encuesta Industrial Anual, Annual Manufacturing Survey). Aggregate trade openness (4) is calculated from the World Bank's World Development Indicators. The share of maquila exports in total exports (5) comes from CNIME. Both the yearly transition rate from informal to formal employment (6) and the share of informal workers (7) come from Gong, Van Soest, and Villagomez (2004). The maquila value added to GDP ratio (8) is from INEGI, Sistema de Cuentas Nacionales de México (Mexican National Accounts System). The share of intermediate imports for maquiladoras in Mexican GDP (9) is from Banco de México, Balanza de Pagos (Balance of Payments). The ratio of Mexican to US GDP (10) is measured in PPP in current US dollars from the World Bank's World Development Indicators. 